\title{
三角形状圧電フィルムセンサ/アクチュエータによる 両端単純支持ばりの振動制御実験*
}

\author{
西垣 勉*1, 川崎陽子*2, 遠藤 満*1 \\ Vibration Control Experiments of a Simply Supported Beam \\ with Triangular-Shaped Piezoelectric Film Sensor/Actuator \\ Tsutomu NISHIGAKI*3, Yoko KAWASAKI and Mitsuru ENDO \\ ${ }^{* 3}$ Tokyo Institute of Technology, Dept. of Mechano-Aerospace Engineering, 2-12-1, O-okayama, Meguro-ku, \\ Tokyo, 152-8552 Japan
}

\begin{abstract}
Vibration control experiments of a simply supported beam using piezoelectric film (PVDF) sensor/actuator are carried out to verify that the triangular-shaped film pair is effective for multi ${ }^{-}$ modes vibration control in comparison with the rectangular-shaped film pair. In the experiment, analog circuits are used to implement DVFB (Direct velocity feedback) control law. Frequency responses of displacemet of a beam subjected to a concentrated harmonic force are measured with sensor outputs and feedback voltages, and those show good agreement with the theoretical results. As predicted theoretically, it is shown in the present experiments that all of the first three vibrational modes are efficiently controlled by the triangular-shaped film sensor/actuator, whereas the rectangular-shaped film sensor/actuator has no control effect against the anti-symmetrical vibrational modes, i. e., the second mode.
\end{abstract}

Key Words: Experimental Study, Vibration Control, Piezoelectric Film Sensor and Actuator, Simply Supported Flexible Beam, Triangular-Shaped Film

\section{1. 緒言}

圧電フィルムは，柔軟で軽薄なシート状の素材であ り，その最大の特徴として，自由な形状に成形して使 用できるということがあげられる。よって，本素子を 振動制御のための分布形センサ/アクチュエータとし て採用し，適切な形状に成形した上で構造物に貼付し て一体化させることによって, 知能化されたシンプル な構造物を創製できる可能性があると考光られる。こ の場合，センサ/アクチュエータの形状によって，結果 として得られる制御効果は大きく異なってくるものと 予想されるが，これらの関係はまだ十分に解明されて いるとはいえない. 压電フィルムをセン少あるいはア クチュエータとして用いる振動制御問題を取扱った従 来の研究をセンサ/アクチュエータの形状の観点から 総括すれば，大きく二つに分けられると思われる。ま ず第 1 には，特定の振動モードの検出あるいは制御を 目的として，振動モードのひずみ関数状にセンサ/ア クチュエータの形状を決定する model sensor/

\footnotetext{
*原稿受付 1999 年1月 19 日.

*1 正員, 東京工業大学工学部 (雪 152-8552 東京都目黑区大岡 山2-12-1).

*2 東京工業大学大学院.

E-mail : tnishiga@ mes.titech.ac.jp
}

actuatorがあげられるが(1)(2)，本手法は多くのモード を同時に制御する目的には適さない。第 2 は多モード を同時に制御するために, 最も単純かつ基本的な形状 である長方形状センサ/アクチュエータを用いた研究 であり，著者らも片持ばりにこれらを複数対貼付する ことにより多モードが同時に制御できることを示し た(3).しかし長方形状ではフィルムの貼付範囲におい て逆対称となる振動モードについては検出あるいは操 作できなくなることが示唆されており ${ }^{(4)}$, フィルムの 貼付条件によっては着目する周波数帯域内に制御不能 に陌るモードが存在してくる可能性がある.よって， 分布形センサ/アクチュエータによる広带域に渡って の振動制御を達成させるためには，センサ/アクチュ エータ形状に焦点をあてた設計手法の確立が求められ ているといえよう。

著者らは，この問題に取組むための一つの統ロとし て，前報(5)に扔いて，はりを制御詨象としてとりあげ, まず，任意のフィルム形状に関して一般的な基礎方程 式を導出し，これを長方形状抢よび長方形状についで 基本的と考えられる幅が一次関数状に変化する三角形 状(4)センサ/アクチュエータに適用することによって, 多くの振動モードを制御するためには，長方形状フィ ルムよりも三角形状フィルムのほうが適しているとい 
う物理的考察を行った，さらに，直接速度フィードバ ック型制御を行った場合の数值解析を行い, 長方形状 フィルムでは検出・制御できない，貼付範囲で逆対称 となる振動モードでも三角形状フィルムによれば検 出・制御が可能であることを示し，また，片持ばりを 用いた実験を行い，実際に三角形状フィルムセンサ/ アクチュエータの動作特性に関する予備的検討を行っ た、本論文ではそれにひき続き，前報の理論解析結果 を実験的に検証するという立場から，特に三角形状セ ンサ/アクチュエータが貼付範䎴で逆対称となる振動 モードを検出/制御できることを実験的に実際に立証 し，三角形状センサ/アクチュエータの長方形状セン サ/アクチュエータに対する多モード振動制御に扔け る優位性を示すことを目的とする。そこで, 逆対称形 状の振動モードを有する代表的なはり構造物である雨 端単純支持ばりを制御対象としてとりあげ，その一点 に調和励振入力が加わる場合の定常応答について笑験 を行い,これら二種類の形状の区電フィルムを用いた 場合の制御効果を定量的に比較し, さらに理論解析結 果とよく一致することを示す。

\section{2. 実験}

$2 \cdot 1$ 概要 前報(5)で示したように，长方形状セ ンサ/アクチュエータがその特性から，雨端で傾きの 等しくなる逆対称の振動モードに詨してはセンサの検 出量およびアクチュエータの操作量が見かけ上零とな り不可観測・不可制御となるのに対し，三角形状セン サ/アクチュエータはより適応性のある特性を有して 㧍り，逆対称の振動モードに対しても何らかの制御效 果を発揮することが期待される。本実験においては， これを立証することに力点をおき，さらに理論解析結 果との定量的な比較を試みる、したがって，装䐈の設 計に扔いては，両端単純支持の境界条件を満足させ㛜 密に逆対称の振動モード形状が実現可能となること， ならびにこの境界条件に影響を与えることなくはりに 集中加振力を与之, かつその加振力を同定可能とする ことを念頭においた。そこで，境界条件については， はりの両端を薄板で支持することとし，加振力の入力 には細いワイヤーを用いることを基本にした。また， 三角形状フィルムと長方形状フィルムを用いた場合の 制御効果を同一条件で定量的に比較するために，これ ら 2 形状のセンサ/アクチュエータを同一面積とした 上で，それぞれが貼付されたはりを別個に用意して実 験を行うことにした。

$2 \cdot 2$ 実験装置 穾験装置の概要とおもなパラメ 一夕をそれぞれ図 1, 表 1 に示す。長さ $390 \mathrm{~mm}$ ，幅
Table 1 Parameters of the experimental apparatus

\begin{tabular}{|l|cl|}
\hline Young's modulus of beam & $E_{B}=70.6$ & $\mathrm{GPa}$ \\
\hline Length of beam & $l=3.9 \times 10^{-1} \mathrm{~m}$ \\
\hline Width of beam & $b_{B}=4.0 \times 10^{-2}$ & $\mathrm{~m}$ \\
\hline Thickness of beam & $t_{B}=1.0 \times 10^{-3}$ & $\mathrm{~m}$ \\
\hline Density of beam & $\rho=2.69 \times 10^{3}$ & $\mathrm{~kg} / \mathrm{m}^{3}$ \\
\hline Piezoelectric constant & $d_{31}=30.0 \times 10^{-12} \mathrm{C} / \mathrm{N}$ \\
\hline Thickness of film & $t_{C}=40.0 \times 10^{-6} \mathrm{~m}$ \\
\hline Young's modulus of film & $E_{C}=3.1$ & $\mathrm{GPa}$ \\
\hline Relative dielectric constant & $\varepsilon=13$ & \\
\hline
\end{tabular}

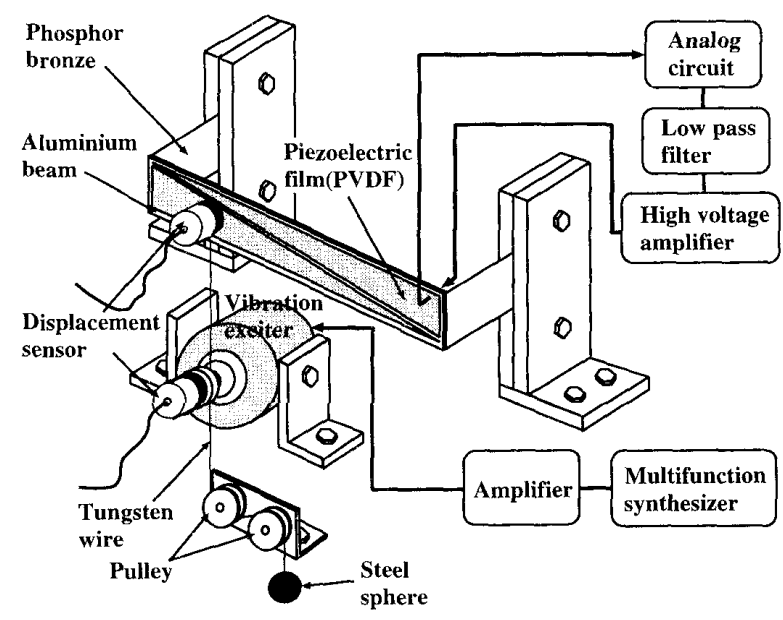

Fig. 1 Block diagram of the experimental apparatus

$40 \mathrm{~mm}$, 厚さ $1 \mathrm{~mm}$ のアルミニウム製のはりの表裏に 厚さ $40 \mu \mathrm{m}$ の二対の三角形状圧電フィルム(PVDF : ポリフッ化ビニリデン)をコロケーションが成立する ようにエポキシ系接着剂を用いて貼付した。同様にし て二対の長方形状尼電フィルムを全長にわたって貼付 したはりを別途用意した。ここで，接着層の厚さは压 電フィルムのそれとほぼ同程度となることが確認され て扔り，この条件下では接着層の影響は無視すること ができ，理論解析に扔いて圧電フィルムとはりは完全 接着されているとみなせる( ${ }^{(3)}$. 実験装置ははりとその 支持部，励振入力部，および制御回路から構成される。

$2 \cdot 2 \cdot 1$ はりの支持方法本実験の上うに厚さ1 $\mathrm{mm}$ 程度の薄肉かつ軽量なはりを取扱う場合，通常の ようにナイフエッジで両端を支持したのでは, 摩擦の 影響等によって良好な単純支持条件を得ることは困難 になる、そこで，はりの両端を薄板で支持することに よって両端単純支持の境界条件を実現させることを試 みた(6). 図 20 ように, 片側 3 本ずつの微小なるじを 用いてはりの両端に愿さ $0.1 \mathrm{~mm}$ のリン青銅板を取 付け，これがはりと直角方向に位置するように他端を 固定支持する。よって，両端に扔いてはりの水平方向 の正進運動は拘束されるにもかかわらず，鉛直軸まわ 


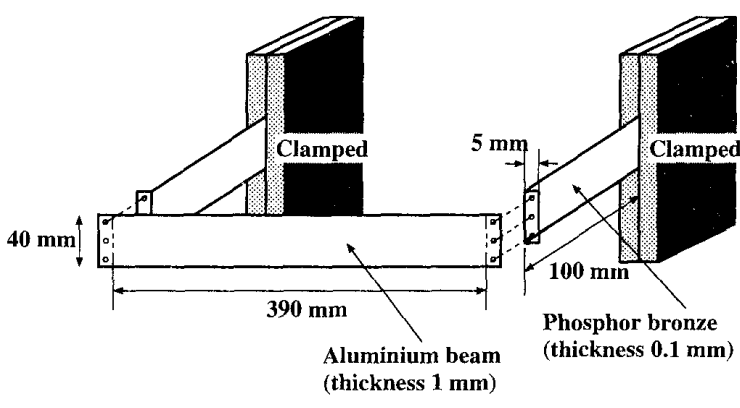

Fig. 2 Simply supported beam

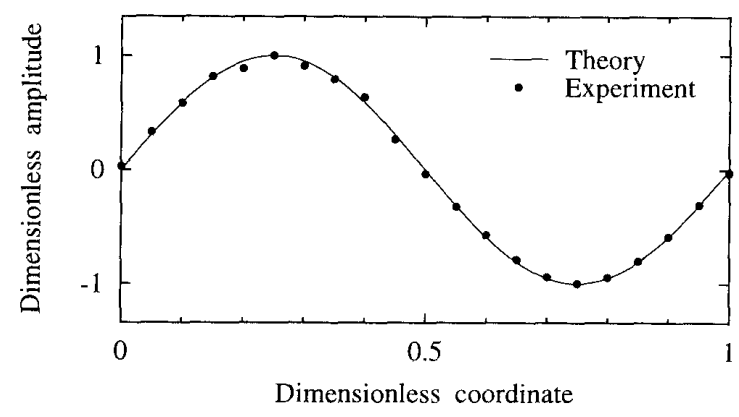

Fig. 3 Mode shape of the second mode

りの回転運動に対しては拘束力が非常に小さくなるた め，画端単純支持の境界条件と合致することが期待さ れる. 以下に本支持方法が妥当であることを検証しよ う.まず，表 2 に 1 次から 4 次までの固有振動数の理 論值と実験值の比較を示す。両者はよく一致している といえる。次に，共振点に扔ける振動モード形状の一 例として，二次モード形状の理論值と実験值を比較し たのが図 3 である.ここで, 横軸ははりの長手方向に 関する無次元化座標, 縦軸は最大值で無次元化した応 答振幅であり，図 3 中, 実線が理論值, 黑丸が実験值 を示す．两者はよく一致しており，実際に逆対称モー ドが励起されていることが確認できた。固有振動数お よび振動モード形状に関する以上の考察から，本支持 方法によって両端単純支持の境界条件が実現できてい ることが検証された.

$2 \cdot 2 \cdot 2$ 励振方法および加振力の同定方法 はり の境界条件に影響を与えることなく励振力を伝達する ために，タングステンワイヤを用いた(7). 図4に示す ように, 動電型加振器のヘッドにジグを設置し, その 中央部に摩擦の小さいテフロンを取付けた。上端をは りに固定した直径 $0.06 \mathrm{~mm}$ のタングステンワイヤを, テフロンの中心に鉛直方向にあけた微小な穴に通し， さらにプーリを介してその下端に質量 $33 \mathrm{~g}$ の鋼球を つり下げた。この機構を用いることで, ワイヤの張力 を一定に保持したまま, その一点を水平方向に強制変 位励振することを可能にした。ここで，タングステン
Table 2 Natural frequencies of the beam

\begin{tabular}{|c|c|c|}
\hline Mode No. & Theory $\mathrm{Hz}$ & Experiment $\mathrm{Hz}$ \\
\hline 1 & 15.35 & 15.15 \\
2 & 61.41 & 60.15 \\
3 & 138.13 & 135.53 \\
4 & 245.65 & 241.31 \\
\hline
\end{tabular}

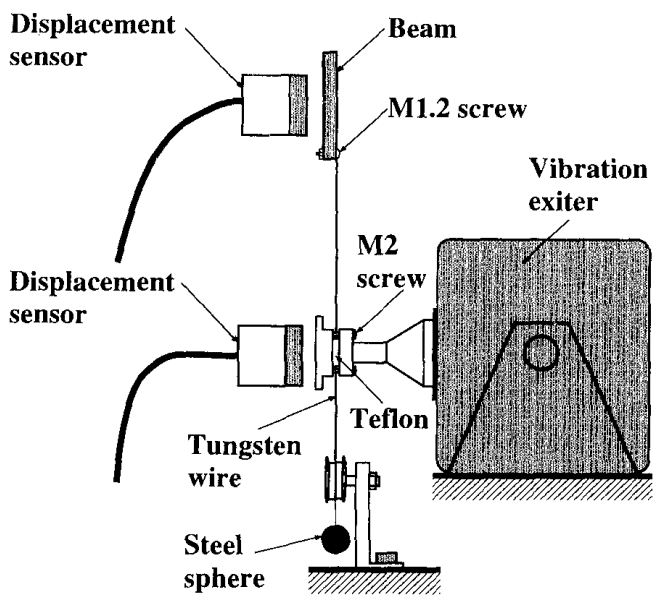

Fig. 4 Excitation method using a fine wire

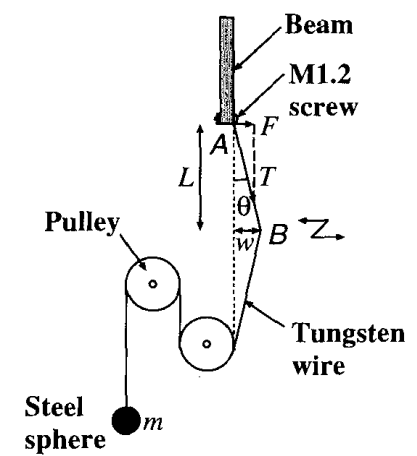

Fig. 5 Estimation of the excitation force

ワイヤは加振器とはり間において, 水平方向に関して は非常に柔軟なばねとして㗢くと考えられる。図 5 は, ワイヤの励振変位とはりへの励振入力ベクトルの 幾何学的関係を示している.ここで, ワイヤが鉛直方 向に対してなす角 $\theta$ が微小な場合には，点 $A$ に入力 される励振力 $F$ を同定する式は次式となる。

$$
F=T \sin \theta \simeq T \tan \theta \simeq \frac{T}{L} w
$$

ここで, $T$ はワイヤの張力, Lはワイヤの長さであ る. また，図 5 に打り点 $A$ と点 $B$ の水平方向相対 変位を $w$ と定義し，これを図 4 に示す 2 個の非接触 変位七ン将(渦電流式, 測定範囲 $5 \mathrm{~mm}$, 分解能 10 $\mu \mathrm{m})$ を用いて測定している。本実験に扔いてワイヤ長 さ $L$ は $60 \mathrm{~mm}$ であるのに対し, 励振変位 $w$ は高々 1〜2 mm であるので, 実際に角度 $\theta$ は微小となり, 式 (1)の近似が成立していると考えてよい。また，ワイ 
ヤの張力 $T$ は，鋼球の質量と重力加速度の積によっ て評価した。本手法によって加振力が同定可能である ことを検証するために予備実験を行った。ワイヤの励 振変位振幅が常に一定となるように加振器への入力を 調整して，はりを調和励振した場合の变位の周波数応 答について, 式(1) から計算される加振力を入力とし て理論解析によって求めた結果と笑際の測定結果の比 較を行った。図 6 に加振力 $F$ を $3.2 \times 10^{-3} \mathrm{~N}$ とした 場合の結果を示吉。ここで, 横軸は周波数, 縦軸は駆 動点の応答振幅であり, 実線が解析結果, 黑丸が実験 結果を示す，両者がよく一致していることから，本手 法により加振力が同定可能であることが確譛できた。 な抢モード減衰比の同定は第 3 章に示す方法で行っ た.

$2 \cdot 2 \cdot 3$ 制御回路前報 センサ/アクチュエータに直接速度フィードバック形 制御を行うことで，すべての振動モードに関して系の

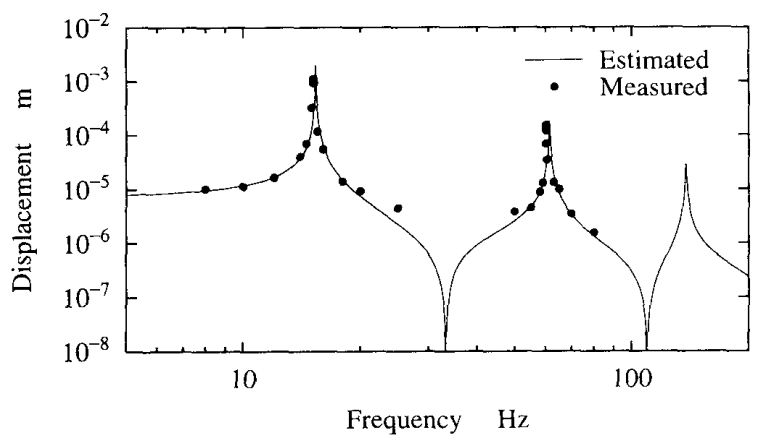

Fig. 6 Comparison of the estimated response and the measured response of the beam

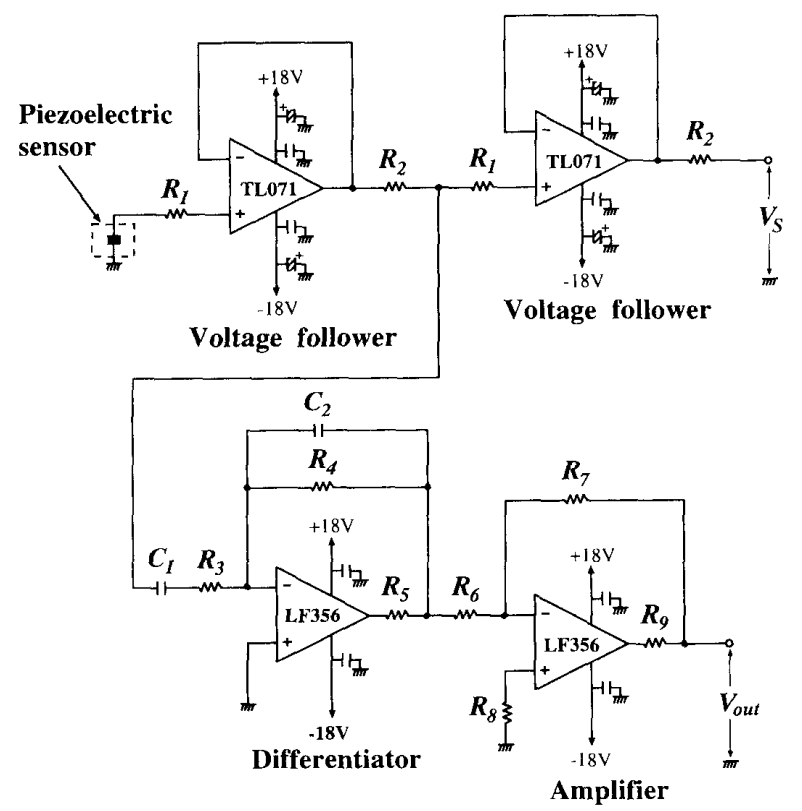

Fig. 7 Analog circuit
安㳬性が保証され，広带域制御に有効であることを示 した．本害験では，この直接速度フィードバック形制 御を実装するために図 7 のようアナログ回路を作成 した(3).ここで用いた抵抗扔よびコンデンサのパラメ 一夕はそれぞれ， $R_{1}=R_{2}=R_{5}=R_{9}=100 \Omega, R_{3}=R_{6}=$ $R_{8}=1 \mathrm{k} \Omega, R_{4}=R_{7}=100 \mathrm{k} \Omega, C_{1}=0.1 \mu \mathrm{F}, C_{2}=0.01$ $\mu \mathrm{F}$ である. 压電フィルムセンサの出力電玨を測定す る場合には，压電効果によって励起されたフィルム表 面電荷が, 測定機器の入力抵抗を通して電流として流 出してしまうため，その結果として電圧降下が生じ正 しい発生電压が測定できない。これは，压電フィルム がコンデンサとして挙動し，機器の入力抵抗とともに フィル夕回路を形成していることを意味する.このフ イル夕回路のカットオフ周波数は機器の入力抵抗と圧 電フィルムの静電容量の積，すなうち時定数に依存す る。そこで本実験回路では压電つィルムセンサとイン ピーダンス整合をとり，センサ出力電压に正確に追従 するボルテージフォロワを前段部分に使用した。一般 にこのようなバッファ回路を用いた場合の入力抵抗は $1 G \Omega$ 以上となるため, 表 1 のパラメータを用いて計 算した压電フィルムの静電容量 $(0.018 \mu \mathrm{F})$ を考慮すれ ばカットオフ周波数は $0.01 \mathrm{~Hz}$ 以下となり, 後述する ように $10 \mathrm{~Hz}$ 以上の振動応答を制御の対象としてい る本研究に打いてはこの影響は無視できる。なお，压 電フィルム自体にも漏れ抵抗が在存するが，体積抵抗 率汃ら計算した本压電つィルムの電気抵抗は $58 \mathrm{G} \Omega$ となり非常に大きいため，動的応答を測定する場合に はほとんど問題とはならない。本回路で測定したセン サ信号 $V_{S}$ を, 後段部分でさらに微分器および増幅器 を通すことによって，直接速度フィードバック形制御 則を実装した。回路の出力信号 $V_{\text {out }}$ はローパスフィ ルタ（カットオフ周波数 $5 \mathrm{kHz}$ )を通して高周波の， イズを除去したのち, 最大出力 $\pm 150 \mathrm{~V}$ の高出力増幅 器によって增幅し, 対応する压電フィルムアクチュエ ータにフィードバック電圧として負荷した。

$2 \cdot 3$ 実験方法発振器によって発生させた正弦 波をアンプで増幅して動電形加振器に入力することに より, ワイヤを変位加振し，はりの一点 $(x=78 \mathrm{~mm})$ に調和励振入力を与えた。そのときの，励振点におけ るはりの変位，センサ出力，フィードバック電圧の定 常振幅を三次モードまでの帯域にわたって測定し，そ れぞれを加振力の大きさで割った值を $\mathrm{dB}$ 表示して周 波数応答曲線を求めた。この測定を三角形状および長 方形状フィルムが貼付されたはりを用いて非制御時お よび制御時についてそれぞれ行った。また, 制御時に おけるフィードバックゲインは 10 倍とした。 


\section{3. 実験結果と理論解析結果の 比較および考察}

一対の三角形状センサ/アクチュエータを用いた場 合の非制御時，扢よび制御時の定常状態における変位 (駆動点コンプライアンス), センサ出力, フィードバ ック電圧の周波数応答について，実験結果を理論解析 結果と比較したのが図 8〜10である。ここで, 図 8 と 9 において，それぞれ( a )が非制御時，(b)が制御時 の応答を示している。また各図において，横軸は周波 数, 縦軸は励振力の大きさで割った值を $\mathrm{dB}$ 表示した 応答の定常振幅を示し, 図 8 においては $0 \mathrm{~dB}=0.201$ $\mathrm{m} / \mathrm{N}$, 図 9 と 10 に颃いては $0 \mathrm{~dB}=0.58 \mathrm{~V} / \mathrm{N}$ にとつ ている．図中，実線が理論解析結果，白丸が実験結果 である。理論解析において使用した各モいド減衰比 は，実験に扮ける減衰自由振動応答波形から同定した ものであり，一〜三次モードについてそれぞれ $1.52 \times 10^{-3}, \zeta_{2}=2.77 \times 10^{-3}, \zeta_{3}=3.43 \times 10^{-3}$ である. 全体を通して，理論值と実験值はよく一致しているこ とが確認できる。また，二次モード(逆対称モード)に 対しても制御効果があることが確認できた。ここで， 高次モードになるにしたがって，実験における制御効 果が理論解析のそれよりも小さくなる傾向にあるが,

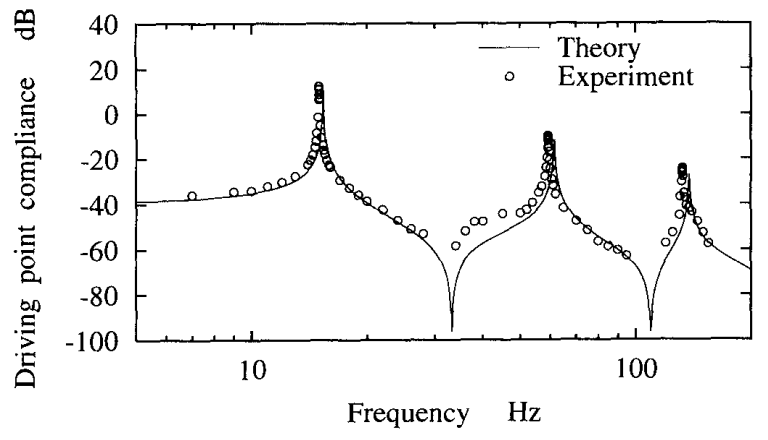

(a) Without control $(0 \mathrm{~dB}=0.201 \mathrm{~m} / \mathrm{N})$

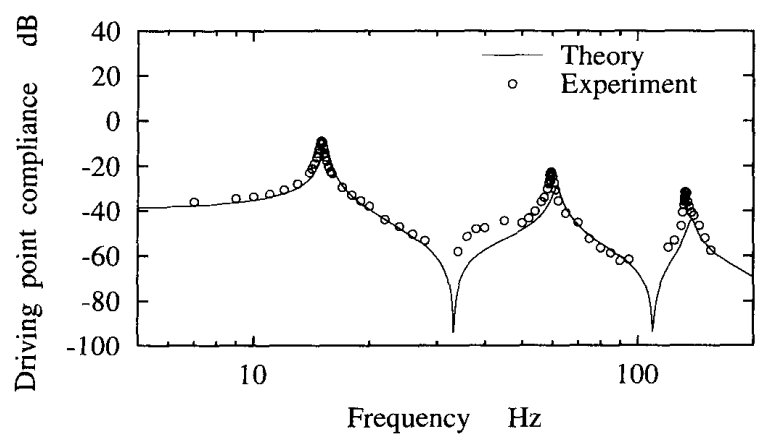

(b) With control $(0 \mathrm{~dB}=0.201 \mathrm{~m} / \mathrm{N})$

Fig. 8 Displacement response of the beam with triangular sensor/actuator
これは，実験においては制御器に近似微分回路を用い ているのに対し, 理論解析では理想的な微分演算を施 しているためこの差異が高周波になるにしたがって現 れたものと考光られる. 次に, 三角形状フィルムと同 一面積の長方形状フィルムセンサ/アクチュエータを 二対貼付したはりについて，このうち一対を作動させ て実験した場合の非制御時，および制御時の変位(駆 動点コンプライアンス)の周波数応答を図 11 に示す。 ここでも理論值と実験值はよく一致しているが, 三角 形状フィルムと長方形状フィルムの制御効果を比較す ると, 長方形状フィルムでは逆対称モード (二次モド）に対しては制御効果が非常に小さいことがわかる. そこで，このフィルム形状による制御効果の違いをよ り明確にするために, 1 次から 3 次までの各共振ピー

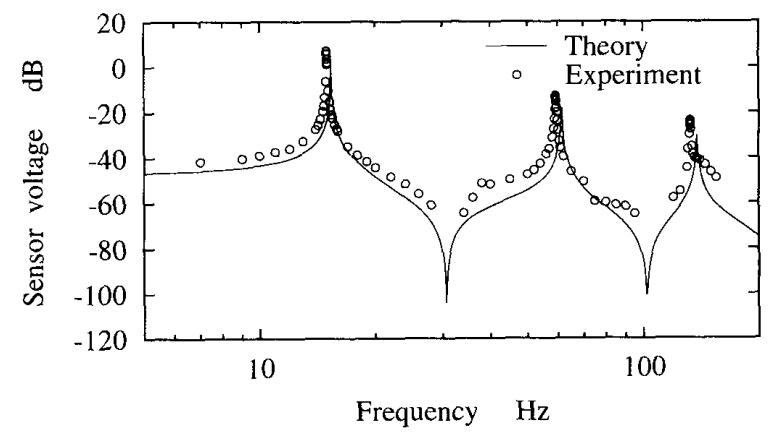

(a) Without control $(0 \mathrm{~dB}=0.58 \mathrm{~V} / \mathrm{N})$

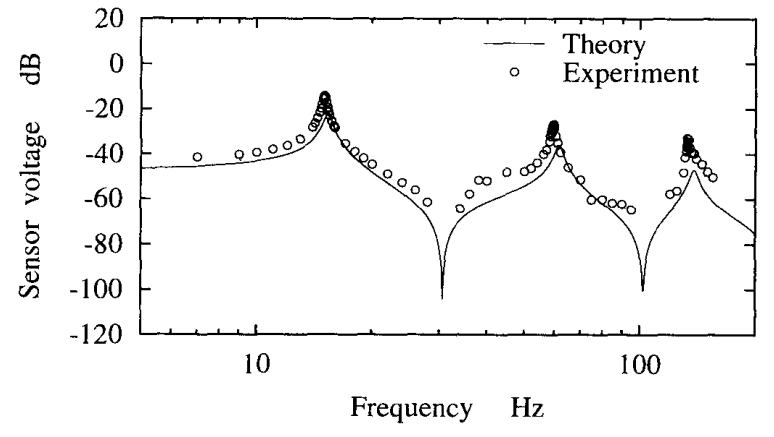

(b) With control $(0 \mathrm{~dB}=0.58 \mathrm{~V} / \mathrm{N})$

Fig. 9 Response of the triangular sensor

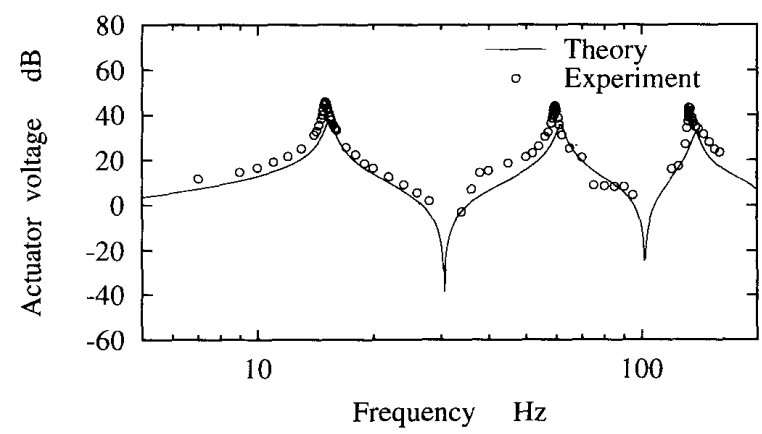

Fig. 10 Feedback voltage applied to the triangular actuator $(0 \mathrm{~dB}=0.58 \mathrm{~V} / \mathrm{N})$ 


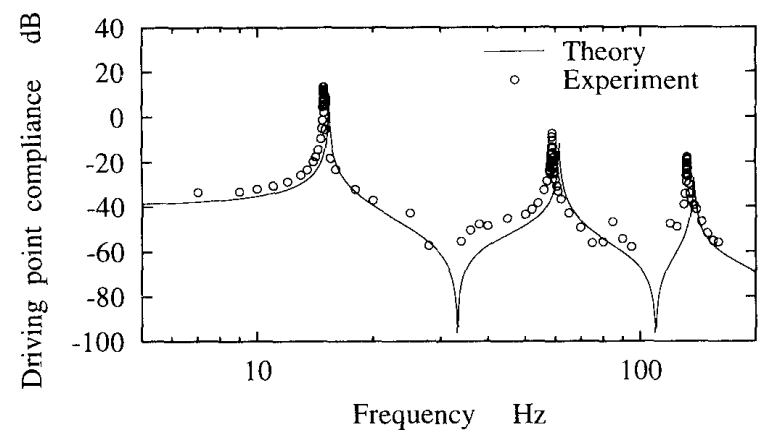

(a) Without control $(0 \mathrm{~dB}=0.201 \mathrm{~m} / \mathrm{N})$

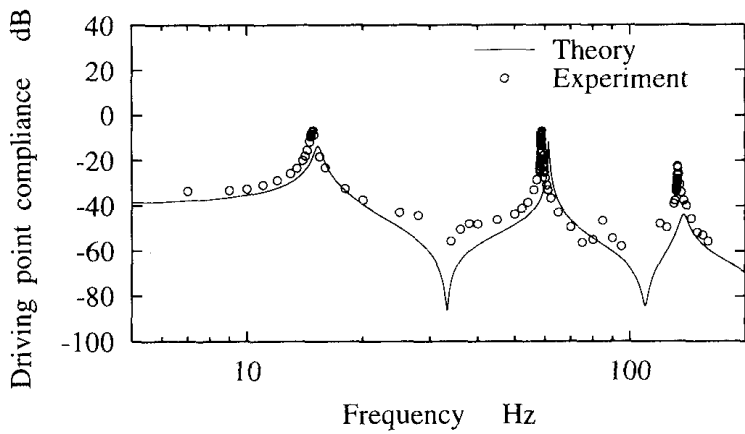

(b) With control $(0 \mathrm{~dB}=0.201 \mathrm{~m} / \mathrm{N})$

Fig. 11 Displacement response of the beam with rectangular sensor/actuator

クの振動抑制効果について実験結果と理論解析結果を $\mathrm{dB}$ 表示で比較したのが表 3 である.表 3 より，実験 において，対称モードである一次执よび三次モードに ついては，三角形状フィルムと長方形状フィルムでは ほぼ同等の制御効果が得られていることがわかる。他 方, 長方形状フィルムでは二次モードの振動抑制効果 が $0.1 \mathrm{~dB}$ と皆無に等しいのに対し, 三角形状フィル ムでは理論解析結果とほぼ同等の $14.1 \mathrm{~dB} の$ 制御効 果があり，逆対称モードでも制御できることが実験的 に立証された。

\section{4. 結 言}

本論文では，三角形状庄電フィルムを分布形セン
Table 3 Comparison of control effects

\begin{tabular}{|c|c|c|c|c|}
\hline \multirow{2}{*}{ Mode } & \multicolumn{2}{|c|}{ Triangular film } & \multicolumn{2}{c|}{ Rectangular film } \\
\cline { 2 - 5 } & $\begin{array}{c}\text { Theory } \\
\mathrm{dB}\end{array}$ & $\begin{array}{c}\text { Experiment } \\
\mathrm{dB}\end{array}$ & $\begin{array}{c}\text { Theory } \\
\mathrm{dB}\end{array}$ & $\begin{array}{c}\text { Experiment } \\
\mathrm{dB}\end{array}$ \\
\hline 1 & -22.7 & -21.7 & -22.7 & -20.5 \\
\hline 2 & -18.3 & -14.1 & -0.0 & -0.1 \\
\hline 3 & -16.5 & -9.5 & -16.5 & -12.1 \\
\hline
\end{tabular}

サ/アクチュエータとして用いた両端単純支持ばりの 振動制御について，前報で示した理論解析結果の実験 的検証を行った. 同一面積の三角形状フィルムと長方 形状フィルムについてそれぞれ振動制御実験を行った 結果, 実験結果と理論解析結果が定量的に一致するこ とが確認された。さらに, 長方形状フィルムでは逆対 称モード(偶数次モード)が䚾とんど制御不可能であっ たのに対し，三角形状フィルムでは対象とした 1 次か ら3次までのすべての振動モードに対して制御効果が 確認され，本手法が広带域な制御に適していることが 実験的に検証された。なお，本解析および実験では， 振動制御におけるフィードバックゲインを固定してい るが、これを変化させた場合の制御効果についても調 ぶることによって，より広带域にわたつての振動制御 法について検討していくことを今後の課題としたい.

\section{文献}

(1) Lee, C. K. and Moon, F. C., ASME J. Appl. Mech. 57 (1990), 434-441.

(2) Tzou, H. S. and Hollkamp, J. J., Smart Mater, Struct., 3 (1994), 277-284

(3) 西坄勉・淰加 2 名, 機論, 63-615, C (1997), 3728-3734.

(4) Burke, S. E. and Hubbard, J. E. Jr., Contr. Dyn. Sys., 36 (1990), 223 273

（5）西垣勉・洼加2名，機論，65-633，C(1999)，1937-1945.

(6) Ochs, J. B. and Snowdon, J.C., J. Acoust. Soc. Am. 58 4 (1975), 832-840.

(7) Evensen, D. A., ASME J. Appl. Mech., 33 (1966), 553 560 